\title{
Virtue and Prudence from Machiavelli to Racine
}

Racine exhibits a marked indebtedness to the Machiavellian conception of virtue and prudence in several of his tragedies. It has been said that Racine had one great theme, love, and its many manifestations and effects, but in Bérénice, Britannicus, and Athalie he emphasized the clash between public responsibility and personal interest. Machiavelli never developed a concise doctrine concerning the term virtù, and his writings inconsistently invoke the notions of virtue and virtuosity. In Il Principe Machiavelli expounds upon the virtue of personal achievement by urging the prince to reach his objectives through ingenuity and foresight. A well-conceived stratagem, well-executed plot, or ingenious deception elicit distinct praise from Machiavelli, especially if they serve some long-term civic purpose. Nonetheless, he is not oblivious to previous conceptions of virtue or devoid of moral sentiment. Virtue for Machiavelli is a cluster of attributes or traits that enables the state to achieve stability, dominance, and finally the communal virtue of justice. His stress on "active citizenship" may have only a tenuous connection to Christian virtue and his clear disdain of the doctrine of humility removes him from the Christian tradition, but in identifying the separate traits of virtue and prudence, he follows the lead of earlier philosophers and theologians.

The Scholastic conception of virtue as expressed by St. Thomas Aquinas emphasizes order and habit, two notions that find repeated emphasis in Machiavelli's Discorsi. St. Thomas argues, as does Machiavelli, that virtue creates order and prudence preserves it, and that a man's habit or disposition is not readily changed:

The way of acting conforms to the disposition of the one acting, for as a thing is, so does it act ... Virtue produccs an ordered operation. Hence virtue is an ordered disposition of the soul .... (53)

Virtue cannot pertain to the body, but only to that which is proper to the soul ....

The practical intellect is the subject of prudence ... Prudence is right reasoning about what is to be done ... Its subject is the practical intellect in its ordering to right will. (60)

Machiavelli's aspirations for the virtuous man may diverge greatly from St. Thomas's, but he concurs that virtue's greatest challenge is to overcome the intransigence or "habit" of the soul.

The Christian doctrines of humility and virtue lie dormant in Racine's profane tragedies, but he also demonstrates in Britannicus and Athalic ${ }^{1}$ that 
the intransigence of the soul can block its access to virtue and even to the practical trait of prudence. Racine gives convincing portraits of the consequences of imprudence in political interaction between monarch and populace in Bérénice and Iphigénie. In Andromaque the hazards of crossing the unpredictable populace are examined in greater detail than in Britannicus, but in all these works fatal consequences may follow upon an erroneous estimation of public allegiance. Racine, interpreter of the ancients, adheres to St. Thomas's belief that virtue promotes order and is consistent with prudent action.

Bérénice pits a ruler against constraining subjects and the virtue of good citizenship against personal affections. The three principal characters, Titus, Bérénice, and Antiochus, form a basis from which the rewards of prudence, virtue, and fortune are examined. And for this intense examination the drama has variously been called the most civilized of all tragedies and no tragedy at all, for there is little or no physical action and no death involved. The emperor Titus faces the condemnation of the Roman senate for courting an alien queen, Bérénice. He agonizes over whether love or duty is the nobler aspiration. He does in some sense compete for Bérénice with a rival, Antiochus, but there is no doubt in Bérénice's mind as to the object of her affections. The tragic element of this drama is to be found not in disastrous physical consequences, but in the realization that Bérénice-her love and devotion - have matured Titus and given him strength to lay the non-Roman world at her feet, but at the same time have engendered a deep sense of duty and civic responsibility in Titus. Good fortune has brought Bérénice to Titus and circumstance will remove her. Titus painfully recognizes that Bérénice's compensation for all her efforts will be rejection and exile from the Roman empire. Bérénice attempts throughout the play to persuade the wavering Titus by exemplifying the virtuous traits of loyalty and devotion. Her exercise of virtue is free of intrigue, and she is never tempted to compromise her values and appeal to the baser elements of Titus's nature. Titus demonstrates, perhaps unwillingly, the triumph of a form of virtù over fortuna. Alternatively, Titus can be seen as a weak figure, whose prudence makes a mockery of Bérénice's virtue. Antiochus devises a plan to abscond with Bérénice, but deviousness is not integral to his nature and the term Machiavellian does not apply. He is a character of great frustration and is at pains to identify himself as a victim of fortuna (5.3.1279-84). At the drama's close, Bérénice and Antiochus depart Rome separately and, as prudence here dictates, stasis is maintained in the Roman state.

Britannicus contains a prime example of contending confidants, Burrhus and Narcisse, who exhibit excesses of prudence and virtiu. But even more important is the question of Néron's turbulent soul. Racine chooses to portray a little-known episode in Néron's life, before he commences on his brutal endeavors, before the disposition of his soul is fixed. Néron, as we see him on the stage, has great latitude in determining for himself the temperament and virtue of his future reign. It is clear that this dramatic strategy is a highly 
conscious construction on the part of the author. As emperor, Néron has the opportunity to shape his times, to vanquish the political intrigues of his mother or to continue in her bloody ways. Machiavelli's general observations apply to the fate of Néron's advisers, to whom Néron looks for guidance: "Io ho considerato più volte come la cagione della trista e della buona fortuna degli uomini è riscontrare il modo del procedere suo con i tempi" (3.9). The drama then is for the possession or control of Néron's soul.

Burrhus can quite justifiably be perceived as a prudent and virtuous soldier, advising Néron to reconcile differences with his powerful mother, Agrippine. He speaks bluntly and without personal ambition for the public good and the maintenance of the Roman state. He finds himself mediating between the domineering Agrippine and the young, but assertive Néron. Indeed, he is thrust into this role by Néron's recent seclusion. To Agrippine, Burrhus urges restraint and prudence: he argues cogently that Néron must be allowed to emerge from her shadow and take charge of the empire. This does not imply necessarily any disrespect for Agrippine or substantial weakening of her influence. As several critics have noted, however, Burrhus misrepresents to Agrippine and grossly underestimates the threatening maneuvers that Néron has recently gained courage to enact:

Vous m'avez de César confić la jeunesse,

Je l'avoue, et je dois m'en souvenir sans cesse.

Mais vous avais-je fait serment de le trahir,

D'en faire un empereur qui ne sût qu'obéir?

Non. Ce n'est plus à vous qu'il faut que j'en réponde,

Ce n'est plus votre fils, c'est le maître du monde ...

L'empereur, il est vrai, ne vient plus chaque jour

Mettre à vos pieds l'empire, et grossir votre cour.

Mais le doit-il, Madame? et sa reconnaissance

Ne peut-elle éclater que dans sa dépendance? . . .

Sur ses aïeux, sans doute, il n'a qu'à se régler;

Pour bien faire, Néron n'a qu'à se ressembler,

Heureux si ses vertus, l'une à l'autre enchaînées,

Ramènent tous les ans ses premières années! (1.2.175-220)

Burrhus seems naively to disregard the fact that Agrippine has a history of uncompromising brutality. His prudencc has offered her acceptance, resignation: Machiavelli could have informed him that a person's habit will not change even if circumstances change (3.9). Agrippine promoted Néron, her son, to the seat of power and now tries to remove him by promoting a rival, Néron's half-brother, Britannicus. Agrippine is galled by Néron's recent seclusion and refusal to grant her an interview. Agrippine's assertiveness could here be judged either prudent or rash. She certainly foresees, as perhaps Bérénice did not, that the man whose cause she advanced will inevitably desire to break free and assert himsclf independent of his original source of strength. She has learned the Machiavellian lesson-contained in Ch. 5 of II 
Principe - that it is more difficult to destroy existing authority than to create a new one.

Burrhus embodies the noble virtue of "active citizenship," but Philip Butler has effectively dismissed the view of Burrhus and Narcisse as Néron's Good and Bad angel:

Burrhus, as well as Narcisse, is of course far more elaborate and characterized than the average confidant. His public-spirited loyalty towards Néron, his efforts at preserving peace between the rival factions in Rome entitle him to the sympathy he usually arouses. In various ways, however, there are flaws in his character ... The incorruptible moralist was also the man who took Néron to the praetorians and had him proclaimed on Agrippine's orders after the murder of Claudius. Perhaps he was a subordinate who knew nothing: has he still discovered nothing? Is he such a simpleton that he can believe that Rome has freely elected Néron as Emperor? (43)

Perhaps, as Machiavelli suggests, Burrhus's thinking is not in conformity with the times. Of course, Burrhus expresses his attitudes almost exclusively in the presence of Agrippine or Néron; he is naturally constrained not to represent Néron as a unworthy usurper of the empire. His practical purpose is to engender peaceful relations between mother and son, not to inflame them and arouse public unrest. It is fair to say that Burrhus speaks judiciously within the confines of his office and authority. It is perhaps not virtuous in the Christian sense to aid in perpetuating the reign of a tyrannical and bloodthirsty figure such as Agrippine, but Burrhus offers staunch and even-handed support of political stability for its own sake. Machiavelli's preference for timely action - to achieve security of the state - over retiring Christian virtue is well-documented in I Discorsi, and is not unlike Burrhus's attempts at temporizing for the benefit of all Rome. Burrhus expresses beliefs that hold the state in highest esteem, that look to past examples, as does Machiavelli himself, for a vigorous combination of republican freedom and monarchial strength. Butler writes:

Respect for the past means respect for the law, which must contain the caprices of the great, the violence of the mob, and the arbitrary actions of the ruler. For Burrhus, following the Augustan line, sees, or pretends to see, no contradiction between the Republican institutions and the presence of a monarch, who is no doubt to act as guardian of the law, and, if necessary, to enforce 'freedom' from above. Do not let us be too hard upon Burrhus: politicians have to compromise. The notion of freedom is essential to Burrhus, because it is a clear, established value, the objective character of which is guaranteed by centuries of acceptance; and Néron correctly understands the gist of his appeal when he perceives that it rests upon the notion of value. Indeed Burrhus' approach to the whole tangle of passions and political rivalries in Britannicus is dominated by the concept of indisputable values. Political values, reinforced by family values. (44-45)

Machiavelli expounds a comparable doctrine that finds merit in an adaptable blend of decisive dictatorial resolve in time of emergency and the resource of republican diversity in time of peace: 
E si vede che '1 Dittatore, mentre fu dato sccondo gli ordini publici c non per autorità propria, fece sempre bene alla città: perché c' nuocono alle republiche i magistrati che si fanno e l'autoritadi che si danno per vic istraordinaric, non quelle che vengono per vic ordinaric, come si vede che scguì in Roma in tanto processo di tempo, che mai alcuno Dittatore fece sc non bene alla republica...

E veramente intra gli altri ordini romani questo è uno che merita essere considerato c numerato intra quegli che furono cagione della grandezza di tanto imperio: perché sanza uno simile ordinc le cittadi con difficultà usciranno degli accidenti istraordinari. Perché gli ordini consucti nelle republiche hanno il moto tardo, non potendo alcuno consiglio né alcuno magistrato per se stesso operare ogni cosa, ma avendo in molte cose bisogno l'uno dell'altro; c perché nel raccozzarc insicme questi voleri va tempo, sono i rimedi loro pericolosissimi quando egli hanno a rimediare a una cosa che non aspetti tempo. $(1.34,165-66)$

Of course, in his commentary on Titus Livy's history, Machiavelli takes the Roman empire as his prime example of flexible yet strong government.

Narcisse is a man of equal energy and greater ambition than Burrhus, but Burrhus's civic-minded loyalty is replaced in him by impetuous virlu. Self-serving and lacking compunction, Narcisse has won his high place in Néron's service with such deceptive dexterity as to make him a fitting rival of Agrippine herself. He easily wins the trust of the young Britannicus and manipulates him. As a dramatic creation, however, his very concentration on scheming and malicious exploits makes him appear at first a narrow Machiavellian and a mere foil for Néron's emerging monstrous nature. Butler concludes:

Narcisse does not, any more than Burrhus, so much admired by Boileau, attain completc, organic coherence. Again the character is fully alive: if Burrhus attracts immcdiate sympathy, Narcisse arouses instant odium. His treachery, his cynical amusement at the trust his ward shows him, and when Néron is prepared to sparc his brother, the formidable pressure he exerts upon the Emperor to bring about the murder of his victim, all this morc than explains the cxclusively moral vicw critics have taken of Narcisse as a mere evil-doer and another example of the traditional character in seventeenth-century theatre, the 'mauvais consciller.'

Nevertheless, Narcisse's political analysis is essentially sound, and the frightening means he advocates for securing Néron's complete sovereignty are somewhat justifiable. Whether Burrhus acknowledges it or not, Agrippine is determined in her attempt to promote Britannicus. Agrippine's past provides ample evidence that she will resort to the most extreme measures to achieve her goals. It may be that Narcisse's pernicious inclinations are in this instance politically fitting and expedient. He is certainly unwavering in his mission and determination. He pours his vile counsel as smoothly into Néron's ear as Britannicus's. Narcisse adeptly exploits Néron's sense of pride in his efforts to counter Burrhus and silence Britannicus permanently:

Burrhus ne pensc pas, Scigncur, tout ce qu'il dit: 
Son adroite vertu ménage son crédit.

Ou plutôt ils n'ont tous qu'une même pensée:

Ils verraient par ce coup leur puissance abaissée;

Vous seriez libre alors, Seigneur; et devant vous,

Ces maîtres orgueilleux fléchiraient comme nous.

Quoi donc? ignorez-vous tout ce qu'ils osent dire?

"Néron, s'ils en sont crus, n'est point né pour l'empire;

"Il ne dit, il ne fait que ce qu'on lui prescrit:

"Burrhus conduit son coeur, Sénèque son esprit . .."

Ah! ne voulez-vous pas les forcer à se taire? (4.4.1451-69)

Narcisse's purposes will not brook delay, and because of this he is more prone to imprudence than Néron. After the murder of Britannicus, he unthinkingly chases June, Britannicus's betrothed, into the maddened Roman crowd and is torn limb from limb. Néron, the "budding monster," has the presence of mind not to test or challenge the violent mob and, as a result, lives on to secure his reign. This episode, described by Burrhus in a very few lines, is the most dreadful and telling particular in the maturing process of Néron. He has learned the value of prudence from Burrhus and Narcisse and has applied it to good effect. Burrhus is sure to face exclusion from Néron's inner circle of advisors or exile; Narcisse is dead. Néron has succeeded both of his mentors. At the drama's close, Agrippine is left only to wonder what fate awaits her. History tells that she, too, was one of Néron's victims.

Racine is close to Machiavelli's estimation of human character in demonstrating that fixed personality and unpredictable circumstance prevail over the most idealistic or heroic of intentions and efforts. Racine's literary predecessors, Corneille and the Baroque tradition, honored moral courage and strength of will. Racine saw man as subject to passion and accident. In large part, Machiavelli wishes to reduce the threat of fortuna and submit political interaction to scientific analysis. Machiavelli's psychology is noted for its lacunae, as well as its disinterest in foibles and idiosyncratic traits. Knowledge is at a premium for the Florentine and his Prince. Subtlety gives nothing to obscurity; guile attempts no self-justification. Deceit is deliberate and unmuddled by moral concerns, though Machiavelli never champions evil or wanton destruction. Machiavelli finds man's moral redemption not in retreat from worldly concerns and a contemplative life, but, as Bruce Mayer explains, in communal involvement:

Although man's social being tends to be marred by the force of his passions, he still possesses some positive social qualities. These qualities are crucial for Machiavelli's conception of politics, because without them, no government, no matter how carcfully devised, could function to the benefit of the collectivity. A sense of justice is the basis for durable social intercourse among private citizens. Machiavelli argues that a man has a natural tendency to render good for good, even though he recognizes that this reaction is subject to conflict of interest in any given situation. (31)

Both Racine and Machiavelli restrict the scope of man's active mental 
capacities, his virtuc and prudence, to be outside the core of his inflexible innate character. Racine's personages are far from scientific in their reasonings, but do possess a horrifying sclf-knowledge. As Bowra says, Racine produced figures who are spectators in their own catastrophe. Racine's figures face powerful emotional forces, but these forces are like Machiavelli's in that they are explicable, identifiable. They may be insurmountable and brutally indifferent, but they are not amorphous and intangible. Both writers seem consciously to stop at a certain depth of analysis into the underlying motives for human behavior. Machiavelli's analyses of character and human potential often verge on tautologous statements:

Perché e' si vede che gli uomini nelle opere loro procedono, alcuni con impeto, alcuni con rispetto e con cauzione. E perché nell'uno e nell'altro di questi modi si passano e termini convenienti, non si potendo osservare la vera via, nell'uno e nell'altro si erra. Ma quello viene ad errare meno ed avere la fortuna prospera che riscontra, come ho detto, con il suo modo il tempo, e sempre mai si procede sccondo ti sforza la natura. Ciascuno sa come Fabio Massimo procedeva con lo esercito suo respettivamente $c$ cautamente discosto da ogni impeto e da ogni audacia romana, e la buona fortuna fece che questo suo modo riscontrò bene con i tempi. $(3.9,344)$

Taken as advice, this seems quite ambiguous; for an excess of action (impetuosity) or thought (caution) should be avoided, yet Machiavelli offers the individual no methodology for determining the compelling trends of nature. Man is considered almost as an atomic unit, unchangeable and subject to his own predilections. We learn here only that those who do not go about things in the right way make mistakes; this seems true without need of analysis. Later, Machiavelli restricts our options by denying us personal reform:

E che noi non ci possiamo mutare, ne sono cagioni due cose. L'una, che noi non ci possiamo opporre a quello a che c'inclina la natura; l'altra, che avendo uno con uno modo di procedere prosperato assai, non è possibile persuadergli che possa fare bene a procedere altrimenti: donde ne nasce che in uno uomo la fortuna varia, perché ella varia i tempi ed egli non varia i modi. Nascene ancora le rovine delle cittadi, per non si variare gli ordini delle republiche co' tempi, come lungamente di sopra discorremo. Ma sono più tarde, perché le penono più a variare; perché bisogna che venghino tempi che commuovino tutta la republica, a che uno solo col variare il modo del procedere non basta. (III.9, 345)

Machiavelli tells us then that personal reform is impossible, institutional change requires upheaval, and were personal reform achicved, it would be insufficient to induce public reform. He may have educated us through his experience about the mechanisms of change, but has enlightened us little about the reasons for humanity's underlying inflexibility. The scope of application of virtue and prudence seem by this discussion to be greatly restricted; only those fortunate enough to have natures in accord with present circumstances have any promise of reward for their efforts. Consequently, the diversity of the community is the greatest safeguard against excesses of character and 
altered circumstances. Neither writer seems inclined to formulate new psychological phenomena or measures. Machiavelli and Racine share a rationalistic psychology, in which motives and forces are assayable; their psychology is not diagnostic, does not deal with causes of mental disturbance or social disorder. Machiavelli works primarily from the simple premise that men are inclined to evil and ambition. Perhaps he felt that the causes if known would not lead to solutions of political upheaval. Machiavelli advocates in $I$ Discorsi a republican political structure which incorporates mechanisms for adjustment and adaptation. Machiavelli never denies that man can perceive the urgency of his situation and its consequences, yet, like Racine, he suggests that man's nature or habit may prevent him from executing reform and averting catastrophe.

Machiavelli and Racine agree that the highest virtue for a government is stability of its institutions. They disagree sharply, however, on the best method for attaining stability. Racine favored until his death an absolutist monarchy as the final establishment of order, whereas Machiavelli detected an inevitable evolution in political dealings and, in fact, alerted any prospective Prince that a mastery of continual adaptation is paramount for conducting a healthy state through generations of change. In his later Christian plays, Racine does not lament the rigid morality and divine vengeance of God. In Ch. 18 of I Discorsi, Machiavelli warns of the rigidity of institutions and the incumbent danger when social or political reform lags behind social change or when personal ambition sours the political process or constitution of the state. Machiavelli distinguishes between the institutions or constitution of a government and the laws enabling magistrates to maintain order. His distinction points out the relative transience of each entity and the relative gravity in correcting defects. It is a familiar pattern of Machiavelli's thought that the more ingrained, established, or powerful an aspect of government, the more virulent, inflexible, or destructive is its opposite:

Poteva uno tribuno e qualunque altro cittadino proporre al Popolo una legge, sopra la quale ogni cittadino poteva parlare o in favore o incontro, innanzi che la si deliberasse. Era questo ordine buono, quando i cittadini erano buoni: perché sempre fu bene che ciascuno che intende uno bene per il publico lo possa proporre, ed è bene che ciascuno sopra quello possa dirc l'opinione sua, acciò che il popolo, inteso ciascuno, possa poi eleggere il meglio. Ma diventati i cittadini cattivi, diventò tale ordine pessimo: perché solo i potenti proponevono leggi, non per la comune libertì ma per la potenza loro, $c$ contro a quelle non poteva parlare alcuno per paura di quelli; talché il popolo veniva $\mathrm{o}$ ingannato o sforzato a diliberare la sua rovina. $(1.18,141)$

It would perhaps be inappropriate to suggest that Machiavelli's historical interpretations are as artful as Racine's dramas; yet his selectivity and emphasis do suggest a certain fatality to the fluctuations of political enterprises monarchial or republican. But as with Racine, rhetoric never supplants reason, form never suffices to fill an argument. Machiavelli seems keenly aware of 
the difficulty for the concerned citizen in perceiving the gradations of decay and corruption in his contemporary society. Machiavelli's dogged pursuit of reliable methods of analysis and remedy can be considered safe from accusation that he detects within each situation or circumstance those particulars that provide for a well-rounded and balanced exposition. One could more justly accuse him - as from his conclusion on the renovation of defective institutions - that his estimation of human iissight sometimes degenerates into distrust of intellection and faith in arms:

Perché altri ordini e modi di vivere si debbe ordinare in uno suggetto cattivo che in uno buono, né può essere la forma simile in una materia al tutto contraria. Ma perché questi ordini, o e' si hanno a rinnovarc tutti a un tratto, scoperti che sono non essere più buoni, o a poco a poco in prima che si conoschino per ciascuno, dico che l'una e l'altra di queste due cose è quasi impossibile. Perché a volergli rinnovare a poco a poco, conviene che ne sia cagione uno prudente che vegga questo inconveniente assai discosto, e quando e' nasce. Di questi tali è facilissima cosa che in una città non ne surga mai nessuno, e quando pure ve ne surgessi, non potrebbe persuadere mai a altrui quello che egli proprio intendesse; perché gli uomini usi a vivere in un modo non lo vogliono variare, e tanto più non veggendo il male in viso, ma avendo a essere loro mostro per coniettura. Quanto all'innovare questi ordini a un tratto, quando ciascuno conosce che non son buoni, dico che questa inutilità che facilmente si conosce è difficile a ricorreggerla; perché a fare questo non basta usare termini ordinari essendo i modi ordinari cattivi, ma è necessario venire allo straordinario, come è alla violenza ed all'armi, e diventare innanzi a ogni cosa principe di quella città e poterne disporre a suo modo. $(1.18,141-42)$

This descent to the use of arms shares some of the pessimism found in $\mathrm{Ra}$ cine's tragedies of factional as well as familial conflict. In both Britannicus and Athalie, a conflict between virtue and political necessity resolves itself though violence, and the relative virtues of the combatants seem ultimately incidental to their virtù and force of will. In both dramas, the victor "disposes" the state as he sees fit.

The definition of prudence in Machiavelli is especially difficult to assess because prudence dictates neither action nor inaction. Racine displays a similar awareness in his last play, Athalie, where there is a notable recurrence of a counselor transmitting sound and prudent advice to his sovereign. For Burrhus, prudence suggested a cessation of hostility, a mending of differences; in Athalie Mathan urges queen Athalie toward swift action, to subjugate the unruly Jews and quash any possible revolt. Mathan, like Narcisse, possesses many pernicious traits of a stereotypical Machiavellian; nonetheless, his counsels, like Narcisse's, are mere echoes or extensions of his superior's long-standing policies. Athalie has unquestionably resorted to fiendish methods to establish hegemony in her state, Jerusalem, including the massacre of her own grandchildren. ${ }^{2}$ But she has recently been afficted by a bewildering mixture of tender maternal feelings and terrifying dreams. She fails to do away with Joas, a child-but future leader of the Jews and certain 
rival. In Racine's dramatization, Athalie is transfixed and impotent in her actions, forgetful of the risk she runs by entering the Jewish temple. In short, her downfall is made possible by the introduction of virtuous sentiments and motherly affection. John Cairncross makes explicit the connection between Athalie's failure and her accessibility "to feelings of trust, generosity, moderation, and pity. Racine ... shows the same Machiavellian philosophy in action as in his earlier plays" (221). ${ }^{3}$

The success of the conspiracy to overthrow Athalie should not be upheld as a manifestation of poetic justice or some facile assertion by Racine that good eventually triumphs over evil. The "legitimate" conspirator of Athalie, Joad, is far from a model of virtue or moral restraint. His orders upon capturing the distraught queen-however justified or politically prudent-mark him as a fanatical avenger, an agent of God's wrath:

Qu'à l'instant hors du temple elle soit emmenée,

Et que la sainteté n'en soit pas profanée.

Allez sacrés vengeurs de vos princes meurtris,

De leur sang par sa mort faire cesser les cris.

Si quelque audacieux embrasse sa querelle,

Qu'à la fureur du glaive on le livre avec elle. (5.6.1791-96)

Machiavelli and Racine thus establish different bases for an assessment of justice and grounds for exceptional or amoral activity. Analysts of Machiavelli's work point often to the arguments for and against the right of a Prince or monarch to breach moral standards for the sake of the state. ${ }^{4}$ The closing words of Racine's drama echo-in a jejune fashion rare in Racine and as unexpected from Joad - the conviction that vengeance is the province of God alone and his dutiful functionaries:

Par cette fin terrible, et due à ses forfaits,

Apprenez, roi des Juifs, et n'oubliez jamais

Que les rois dans le ciel ont un juge sévère,

L'innocence un vengeur, et l'orphelin un père. (5.8.1813-16)

Racine's stern Jansenist faith contends that no ratiocination could begin to discern or justify God's will. Machiavelli makes no such appeal to divine guidance. A.J. Parel finds the advisor to princes a far more earth-bound creature:

Justice, for Machiavelli, has its roots neither in the divine wisdom nor in the structure of the cosmos, nor in the structure of human reason, but in man's sentiment of gratitude for political security guaranteed by superior force. It has its roots in the materialistic, i. e., the purely animalistic origin of man and society. (66)

No doubt, Racine never argued in favor of adopting ruthless measures to secure political stability. But he, like Machiavelli, recognized the efficacy of such a course and the eternal ironies and contradictions inherent in governing the mass of men. 
These two great observers of the human condition did show parallels in their intellectual devclopment. Like so many in the Renaissance, they revered and emulated the ancients. But aside from that shared heritage, Machiavelli and Racine modified an early extremism. Racine returned to the strict Jansenist Christianity of his youth. Felix Gilbert recognizes that Machiavelli, at least stylistically, adopted a more conventional approach in his commissioned history of Florence (138-9). ${ }^{5}$ Much has been written about Machiavelli's apparent inconsistency in urging the Prince toward political domination while applauding the virtues of republican government in I Discorsi. John Cairncross detects a comparable cvolution from an initial purpose in Athalie:

Racine ostensibly set out to defend absolute monarchy by divine right and ended up by appeals to pity the poor that smack of eightcenth-century humanitarianism. There can be few more striking examples of an artist going far beyond and indeed against the aims that he might normally have been expected to follow. But this seeming paradox need not surprise us. Racine was too rich and complex, too sensitive to the endless contradictions of life, not to reproduce these in his last play. (232)

Neither Machiavelli's nor Racine's wavering of purpose should be interpreted as a conscious change in attitude.

Machiavelli is not equivocal in his usage of virtù as it applies to the general populace. He states bluntly that the populace is less prone to ingratitude and is guilty of fewer faults (1.59) than any prince. In fact, Machiavelli's usage of virtu comes closest to the Christian sense in connection with maintenance of a republic, where virtue is a trait of a people or city. Its opposite, corruption, is perceived as an insidious trait which only generations of time or an exceptional leader such as Solon, Moses, or Lycurgus can remove. ${ }^{6}$ Once corrupt, a people cannot maintain its freedom, according to Machiavelli, unless "the goodness of some one man, conjoined with virtue, should keep it free. Such freedom, however, will last only so long as he lives" (1.17). For Machiavelli, men acting in a group should be treated as little more than a force to control or withstand. As Mayer notes, even the internal conflict of ruler or prince is passed over almost entirely: "Machiavelli does not consider any idea of liberty in which the individual functions as an autonomous political unit. The distinction between the interests of the individual and those of his political persona is not germane to Machiavelli" (33).

Though no explicit reference to Machiavelli appears in Racine's dramatic works, Machiavelli's analytical style and political realism arc commonplace in Racine's dramas. It may seem that Machiavelli's general tendencies of discourse give a disproportionate share of time to cool-headed political calculation and recitation of historical precedent. He tirelessly pursues the virtues of decisiveness and insight into specific confrontations or political frays. Racine similarly creates many such conflicts and consistently suggests that a course of prudence, even when it entails violent action, should supersede the pur- 
suit of personal or emotional aspirations. Racine makes plain the hazards of political imprudence for those as seasoned as Athalie and as immature as Britannicus. Racine offers Titus civic duty as a virtuous alternative to personal affection and, in the spirit of Machiavelli, denies Titus control of more than half of his fate. Racine's method is perhaps closest to Machiavelli's in Agrippine's tirade to Néron in Act IV of Britannicus. Agrippine displays her own unswerving virtù as she represents to Néron her bloody history as a sequence of justifiable conquests for which he should thank her. Néron's silence throughout serves only to emphasize the futility of her rhetoric and the imprudence of tutoring her son in the ways of power.

\section{Santa Clara University}

\section{NOTES}

1 In his introduction to Iphigenia, John Cairncross puts the crises of the play into contemporary focus: "Achilles' triumph over his adversaries is the more remarkable since Racine had previously shown the idealists (such as Britannicus in the play of that name) as speedily disposed of by their craftier foes. Now, it is the turn of the idealists to come off best. The two sets of values ... correspond roughly to the views and interests of the centralized monarchy of Louis XIV and of the independent fcudal lords whom he was trying, in the interests of the unity and greatness of the State, to bring under control." The opposition of the two attitudes is plainly visible in the clash between the elective overlord of the Greeks, Agamemnon, and his powerful vassal, Achilles. In Racine's previous plays, there has been no questioning of the authority of the various kings and queens (except by secret conspiracy). Here, Agamemnon is forcefully reminded by Achilles that it was he (Achilles) that made the king 'the Grecians' chief and [his]" (44).

2 See Racine, Iphigenia 219.

3 Cairncross continues his examination of this religiously inspired play and gives excellent insight into the dramatic potency of Racine's mind and its insuppressible ironies: "But the very fact that Mattan is so revolting underlines the supreme irony of the play. For, had Athaliah taken his advice, she had every chance of worsting Jehoiada's conspiracy" (222).

4 See Machiavelli's discussion of Romulus and Remus in I Discorsi 1.9.

5 Gilbert discusses Machiavelli's adaptation of style and perhaps content to the more humanist inclinations of his patronage and audience. Still, he finds Machiavelli true to himself in his "report of passionate factional struggles and increasing military incompetence." While other humanists' histories memorialized the victorics and valor of the city-state, Machiavelli's depiction "can hardly be considered as an appeal to the Florentines to live up to the greatness of their past" (139).

6 Machiavclli examines the regeneration of a people in I Discorsi 1.9. Della Terza summarizes Machiavelli's greater admiration for the statesman Cesare Borgia (97-98): "La 'Fortuna' è stata ostile a Cesare Borgia che possedeva tutte le 'Virtù' che mente umana possa concepire, tutte le 'Virtù' o quasi tutte, poiché egli commise l'errore imperdonabile di non opporsi alla nomina di Giuliano della Rovere al Papato. Il Principe nuovo, per raggiungere la perfezione dovrebbe dunque essere più 'virtuoso' di Cesare Borgia. Ma è raggiungibile la perfezione? La risposta appare, altraverso varie contraddizioni, alla fine del famoso capitolo XXV del Principe. La 'Fortuna' segue l'uomo come la sua ombra: gli uomini possono essere o 'respettivi' o 'impetuosi;' prudenti come Fabio Massimo, il liviano 'cunctator,' o aggressivi come Giuliano della Rovere. Ora, per quanto il Machiavelli preferisca 'gl'impetuosi' ai 'respettivi' deve riconoscere spassionatamente che quando l'uomo impetuoso viene coinvolto in circostanze che impongono prudenza, i suoi disegni sono destinati a sicura sconfitta." 


\section{WORKS CITED}

Bowra, Mauricc. The Simpliciry of Racine. Oxford: Clarendon, 1956.

Butler, Philip. Racine: Britannicus. Cambridge: Cambridge UP, 1967.

Della Terza, Dante. Forma c memoria. Roma: Bulzoni, 1979.

Gilbert, Felix. History: Choice and Commitment. Cambridge, Mass.: The Belknap Press of Harvard UP, 1977.

Machiavelli, Niccold. The Discourses. Trans. L. J. Walker with revisions by B. Richardson. Bungay, Suffolk: Penguin Books, 1970.

Opere. Ed. M. Bonfantini. Milano-Napoli: Ricciardi, 1954.

Mayer, Bruce. "Machiavelli's Promise to the Citizen: Political Fredom?" Machiavelli Studies 1 (1987): 25-42.

Parel, Anthony J. "Machiavelli on Justice." Machiavelli Studies 1 (1987): 65-81.

Racinc, Jean. Andromache and Other Play's. Trans. J. Cairncross. Bungay, Suffolk: Penguin Books, 1967.

Books, 1970.

Iphigenia, Phaedra, Athaliah. Trans. J. Cairncross. Aylesbury, Bucks: Penguin

Théâtre complet. Ed. J. Morel and A. Viala. Paris: Garnicr Frères, 1980.

St. Thomas Aquinas. Treatise on Virtues. From the Summa Theologiae. Trans. J. A. Oesterle. Englewood Cliffs, New Jersey: Prentice-Hall Inc., 1966. 